\title{
Long-term leaching test of incinerator bottom ash: Evaluation of $\mathrm{Cu}$ partition
}

\author{
Cheng-Fang Lin ${ }^{\mathrm{a}, *}$, Chung-Hsin $\mathrm{Wu}^{\mathrm{b}}$, Yen-Chiun Liu ${ }^{\mathrm{a}}$ \\ ${ }^{\text {a }}$ Graduate Institute of Environmental Engineering, National Taiwan University, Taipei, Taiwan \\ ${ }^{\mathrm{b}}$ Department of Environmental Engineering, Da-Yeh University, Chang-Hua, Taiwan
}

Accepted 7 July 2006

Available online 25 September 2006

\begin{abstract}
Two types of leaching tests were performed on the bottom ash from municipal solid waste incinerators. A short-term batch test specified by the America Nuclear Society (ANS) and long-term column tests with acetic acid ( $\mathrm{pH}$ 5.2) as leaching solution were used to evaluate copper leachability. The $\mathrm{Cu}$ leaching after the 5-d ANS test is about $1 \%$ of the original Cu content of $5300 \mathrm{mg} / \mathrm{kg}$. Upon addition of a stabilizing agent, the $\mathrm{Cu}$ leaching quantity is reduced; the extent of reduction depends on the type of chemical used (phosphate, carbonate and sulfide). The $1.6 \% \mathrm{Na}_{2} \mathrm{~S}$ addition showed negligible $\mathrm{Cu}$ leaching, and $\mathrm{Na}_{2} \mathrm{~S}$ was, therefore, used in subsequent column tests. The 30-d column test indicates a steady increase of $\mathrm{Cu}$ leaching amount with time and reaches about $1.5 \%$ of the original $\mathrm{Cu}$ content after $30 \mathrm{~d}$. A 180 -d column test further increased the $\mathrm{Cu}$ leaching to about 5.1\% of the original $\mathrm{Cu}$ content, whereas no appreciable $\mathrm{Cu}$ leaching was found with the addition of $1.6 \% \mathrm{Na}_{2} \mathrm{~S}$. A sequential extraction was conducted on the raw ash, ash with the addition of $\mathrm{Na}_{2} \mathrm{~S}$ and the residue ash after $30 \mathrm{~d}$ of operation to characterize $\mathrm{Cu}$ affinity for different solid fractions. The data were used to evaluate the fate of $\mathrm{Cu}$ through these interactions.
\end{abstract}

(C) 2006 Elsevier Ltd. All rights reserved.

\section{Introduction}

Large quantities of bottom ash generated and subsequent disposal of bottom ash from the incineration of municipal solid wastes (MSW) have presented a significant problem for municipalities. For example, the annual bottom ash production amounts to approximately 1.33 million tons for a total of $20 \mathrm{MSW}$ incinerators in Taiwan (TEPA, 2004). A common practical management method for bottom ash is landfill disposal. Although bottom ash may meet the toxicity requirements (e.g., test for toxicity characteristic leaching procedures) regarding heavy metals, and hence, it may not be classified as hazardous waste, the eventual leaching of metals in a landfill should be a major concern in terms of affecting bioactivity in the landfill and accumulating high metal concentrations in leachate. Even with the

\footnotetext{
${ }^{*}$ Corresponding author. Tel.: +88622362 7427; fax: +88622392 7653.

E-mail address: cflin@ntu.edu.tw (C.-F. Lin).
}

reuse of bottom ash, the potential metal leaching always hinders its application.

There have been many studies related to metal leaching from bottom ash under different conditions with batch and column studies (e.g., Baba and Kaya, 2004; Polettini and Pomi, 2004). As well as a few investigated leaching mechanisms related to metal status, i.e., equilibrium between dissolved and immobilized metal state (Johnson et al., 1996) and the effect of the presence of dissolved organics on metal leaching (Meima et al., 1999). In general, many factors affect metal leaching, including type and quantity of leaching solution, characteristics of bottom ash, extent of metal immobilized in the bottom ashes, type of immobilized metals, and presence of organics, as well as leaching conditions $(\mathrm{pH}$, oxidation reduction potential, and temperature).

To prevent metal leaching, the addition of stabilizing agents, such as sulfide, phosphate and numerous commercial proprietary products, has been demonstrated to be effective. The insoluble metal compounds formed upon addition of these stabilizing agents are generally controlling 
minerals for limiting metal release. In a study conducted by van Gerven et al. (2005), MSWI-bottom ash was placed in a $\mathrm{CO}_{2}$ chamber $\left(\mathrm{CO}_{2}: 10 \%\right.$ and temperature: $\left.50{ }^{\circ} \mathrm{C}\right)$ and $\mathrm{Cu}$ leaching was reduced from 3.3 to $1.0 \mathrm{mg} / \mathrm{kg}$. Iretskaya et al. (1999) and Reich et al. (2002) indicated that combined chemical and thermal treatments efficiently stabilize heavy metals in MSWI ash. However, long-term evaluation of such stabilized matrices, particularly under adverse conditions, has seldom been performed. Also, data on metal partition onto mineral fractions in the bottom ash (i.e., exchangeable, bound to carbonate, among others) are lacking. The use of sequential metal extraction has been applied to soils (e.g., Tao et al., 2003) for estimating bioavailability of metals to plants and sediments (e.g., Pardo et al., 1990) for potential release into water columns. Recently, Bruder-Hubscher et al. (2002) use sequential extraction to study the release of metals from bottom ash, and reported that $\mathrm{Pb}$ and $\mathrm{Zn}$ can be released under acidic conditions and $\mathrm{Cr}$ leached under strong acidic conditions. Unfortunately, changes in metal partition in bottom ash as a result of adding stabilizing agent and after prolong leaching have not been reported.

Consequently, the objectives of this study were to: (1) evaluate long term metal leaching with or without the addition of stabilized agents; and (2) identify the metal partition in bottom ash before and after the addition of a stabilizing agent. The tasks for meeting the first objective included the use of batch and column leaching tests with acetic acid $(\mathrm{pH}$ 5.2) as the leaching solution. This may simulate the worst conditions in landfill leaching with both low $\mathrm{pH}$ and high amount of organics. The sequential extraction procedures proposed by Tessier et al. (1979) were used for classifying metal partition into different solid fractions present in bottom ash. The macrostructure change in metal fractions upon addition of stabilizing agent should provide a direct evidence for its capability in retarding metal leaching. The metal fraction change after bottom ash has been leaching for a period of time can also shed light as to which metals are being released. In particular, $\mathrm{Cu}$ is our focus of metal interest, since $\mathrm{Cu}$ is usually much more bioavailable in soil and may exert toxicity to plants (Pshlsson, 1989), has high leaching potential (Meima et al., 1999), and is abundant in bottom ash in Taiwan (Chao, 2003).

\section{Materials and methods}

\subsection{Materials}

Bottom ash was obtained from two MSW incinerators; designated as Sample A and B. The ash samples $(25 \mathrm{~kg})$ were obtained at the bottom ash recycling center of each incinerator plant. The ferrous metal and non-ferrous metal are removed immediately on site, either magnetically or manually. Thereafter the bottom ash samples were airdried for 1 week before the experiments. Bottom ash greater than $10 \mathrm{~mm}$ was removed (ca. $90 \%$ less than $10 \mathrm{~mm}$ ) (is to meet the code of controlled low strength materials and road base materials). The dried samples were subject to analysis of $\mathrm{pH}$, moisture content, loss of ignition, and metal content.

X-ray diffraction (XRD) was used to characterize the crystal structure of each ash sample. Raw samples were combined with different stabilizing agents to see the extent of stabilization of bottom ashes. The stabilizing agents used included $\mathrm{H}_{3} \mathrm{PO}_{4}, \mathrm{Na}_{2} \mathrm{CO}_{3}, \mathrm{~K}_{2} \mathrm{HPO} 4$ and $\mathrm{Na}_{2} \mathrm{~S} \cdot \mathrm{H}_{2} \mathrm{O}$; the solubility products for $\mathrm{Cu}_{3}\left(\mathrm{PO}_{4}\right)_{2}, \mathrm{CuCO}_{3}$ and $\mathrm{CuS}$ are $1.4 \times 10^{-37}, 2.5 \times 10^{-10}$ and $8.0 \times 10^{-37}$, respectively (Stumm and Morgan, 1981).

\subsection{Experiments}

Two types of leaching tests were performed: quasidynamic and continuous column tests on both raw and stabilized ash samples. The quasi-dynamic test essentially follows those described elsewhere (ANS, 1986). Briefly, a $25 \mathrm{~g}$ ash sample was added into $500 \mathrm{~mL}$ HAc leaching solution ( $\mathrm{pH} 5.2$ with liquid to solid ratio of $20 \mathrm{~mL} / \mathrm{g}$ ). The reason for using HAc as a leaching solution is that HAc is used in the Toxicity Characteristics Leaching Procedures to determine whether the waste is hazardous waste or not. Further, within the landfill matrix, HAc is the major biological byproduct. Consequently, it is felt that the use of HAc may represent realistic conditions for metal leaching studies.

Periodically ( $2 \mathrm{~h}, 7 \mathrm{~h}, 24 \mathrm{~h}, 2 \mathrm{~d}, 3 \mathrm{~d}, 4 \mathrm{~d}$ and $5 \mathrm{~d}$ ), the leaching medium was replaced with the fresh HAc solution, and the $\mathrm{Cu}$ content was determined on the filtered samples $(0.6 \mu \mathrm{m})$ from the supernatant of the centrifuged leaching solution $(16,000 \mathrm{~g}$ for $15 \mathrm{~min})$. When the results were unexpected, duplicate experiments were conducted.

Several columns ( $5 \mathrm{~cm}$ diameter with $24 \mathrm{~cm}$ height) filled with about $350 \mathrm{~g}$ ash sample were used for observing $\mathrm{Cu}$ leaching of various samples. The upflow velocity was controlled at $24-36 \mathrm{~mL} / \mathrm{h}$ with a pump (Cole Parmer, 7533-71). (Under this flow rate, a 30-day column test is equivalent to approximately 4.4 years of natural rainfall leaching with an average rainfall of $2500 \mathrm{~mm} / \mathrm{yr}$ and both the results of modified ANS tests and column tests are to be correlated.) The same HAc solution ( $\mathrm{pH}$ 5.2) was used as the leaching solution.

The samples with the addition of stabilized agents were initially tested for their stability in the modified ANS 16.1 method (ANS, 1986). The stabilized agents were first added into samples according to the preset weight ratio, mixed for 30 min and then subjected to the above ANS test. Once the best agent $\left(\mathrm{Na}_{2} \mathrm{~S}\right)$ was identified, more detailed studies using $\mathrm{Na}_{2} \mathrm{~S}$ were performed in both ANS and column tests.

\subsection{Analysis}

The $\mathrm{pH}$ was determined in the supernatant of $20 \mathrm{~mL}$ $0.01 \mathrm{M} \mathrm{CaCl}_{2}$ solution containing a 10 -g sample. Measurements of water content, ignition loss and metal content of samples were performed based on the methods outlined in 
the Taiwan's Standard Methods (National Institute of Experimental Laboratory, 2004). The Inductively Coupled Plasma (Perkin-Elmer SCIEX ELAN 5000) was used for determining metal content in ash samples, first digested with the mixture of $\mathrm{H}_{3} \mathrm{PO}_{4}: \mathrm{HCl}: \mathrm{HF}=5: 3: 1$ prior to analysis. The XRD (X-pert PRO, Philips) was used for identifying potential chemical structure based on the JCPDS file data. Intensities over $2 \theta\left(20-80^{\circ}\right)$ at a rate of $3^{\circ} / \mathrm{min}$ were monitored.

Metal concentrations from the leaching tests were determined using atomic absorption spectrometer (Perkin-Elemer 800-2-9). Sequential extraction was performed on three samples (raw bottom ash, ash with the addition of stabilizing agent and column residues) according to the procedures used by Tessier et al. (1979). The procedures and the corresponding metal fractions are illustrated in Table 1.

\section{Results and discussion}

\subsection{Ash characterization}

The mineral contents for bottom ashes are shown in Table 2 with high amounts of $\mathrm{Ca}, \mathrm{Si}$ and $\mathrm{Fe}$, along with other heavy metals. There are noticeable differences in $\mathrm{Ca}, \mathrm{Cu}$ and $\mathrm{Mn}$ concentrations between the two ash samples. The comparison of metal contents present in the bottom ash from the present study with others is not possible since they are dependent on the type of MSW, incinerator operating conditions, and the nature of sample heterogeneity in the bottom ash piles. Nonetheless, elemental composition from the present study is typically in the same range of MSW bottom ashes (e.g., Speiser et al., 2000), with perhaps relatively high $\mathrm{Cu}$ content in two samples tested, or $5000-7000 \mathrm{mg} / \mathrm{kg}$; for comparison, the $\mathrm{Cu}$ content of $2230 \mathrm{mg} / \mathrm{kg}$ was reported by Crannell et al. (2000), $1450 \mathrm{mg} / \mathrm{kg}$ by Bruder-Hubscher et al. (2002) and 280 $560 \mathrm{mg} / \mathrm{kg}$ by Speiser et al. (2000). Further quantitative
Table 2

Mineral content for bottom ash samples

\begin{tabular}{lll}
\hline Analyte & Sample A $(\%)$ & Sample B $(\%)$ \\
\hline $\mathrm{Al}$ & 0.56 & 0.54 \\
$\mathrm{~B}$ & 0.02 & $<0.02$ \\
$\mathrm{Ca}$ & 8.82 & 5.23 \\
$\mathrm{Cd}$ & $<0.01$ & $<0.01$ \\
$\mathrm{Cr}$ & 0.14 & 0.03 \\
$\mathrm{Cu}$ & 0.51 & 0.66 \\
$\mathrm{Fe}$ & 9.01 & 10.63 \\
$\mathrm{~K}$ & 0.95 & 1.09 \\
$\mathrm{Mg}$ & 0.38 & 0.33 \\
$\mathrm{Mn}$ & 0.16 & 0.42 \\
$\mathrm{Na}$ & 1.67 & 1.13 \\
$\mathrm{Ni}$ & 0.05 & 0.03 \\
$\mathrm{~Pb}$ & 0.10 & 0.19 \\
$\mathrm{Si}$ & 12.04 & 12.65 \\
$\mathrm{Ti}$ & 0.89 & 0.75 \\
$\mathrm{Zn}$ & 0.41 & 0.42 \\
\hline
\end{tabular}

analysis of $\mathrm{Cu}$ for those samples used in subsequent leaching tests indicated the total $\mathrm{Cu}$ contents for sample A and B were 5300 and $6600 \mathrm{mg} / \mathrm{kg}$, respectively. These values were used as the initial data for subsequent extraction tests.

The results of XRD for both ash samples (Fig. 1) indicate the presence of $\mathrm{Ca}_{3} \mathrm{Al}_{6} \mathrm{Si}_{2} \mathrm{O}_{16}, \mathrm{Ca}_{8} \mathrm{Si}_{5} \mathrm{O}_{18}, \mathrm{CaCO}_{3}$, $\mathrm{CaSO}_{4}, \mathrm{CaO}, \mathrm{CuO}, \mathrm{Pb}_{3} \mathrm{O}_{4}$ and $\mathrm{SiO}_{2}$; minerals typically combined with different calcium-hydrate phases (Speiser et al., 2000). For two bottom ash samples, pH ranged from 9.1 to 9.3 , moisture averaged $4.5-4.8 \%$ and ignition loss about $5.1-5.3 \%$. The ignition loss is close to the standard $5 \%$ in operating incinerators in Taiwan. The high $\mathrm{pH}$, as well as high alkalinity, in ash samples certainly is the major factor controlling eventual metal leaching.

\subsection{Leaching tests}

The short-term 5-d ANS test results are shown in Fig. 2. The $\mathrm{Cu}$ leaching without addition of any stabilizing agent from Sample A at $5 \mathrm{~d}$ was about $55 \mathrm{mg} / \mathrm{kg}$ (ca. $1 \%$ of the

Table 1

Sequential extraction procedures (Tessier et al., 1979)

\begin{tabular}{|c|c|c|c|}
\hline \multirow[t]{2}{*}{ Fraction } & \multirow[t]{2}{*}{ Extraction agent } & \multicolumn{2}{|l|}{ Extraction conditions } \\
\hline & & Mixing time at $100 \mathrm{rpm}$ & Temperature \\
\hline Exchangeable & $\begin{array}{l}10 \mathrm{~mL} \mathrm{MgCl} \\
(1 \mathrm{M}, \mathrm{pH}=7.0)\end{array}$ & $1 \mathrm{~h}$ & $25^{\circ} \mathrm{C}$ \\
\hline Carbonate & $\begin{array}{l}10 \mathrm{~mL} \mathrm{NaOAc} \\
(1 \mathrm{M}, \mathrm{pH}=5.0)\end{array}$ & $5 \mathrm{~h}$ & $25^{\circ} \mathrm{C}$ \\
\hline Fe-Mn oxides & $\begin{array}{l}20 \mathrm{~mL} 0.04 \mathrm{M} \\
\mathrm{NH}_{2} \mathrm{OH} \cdot \mathrm{HCl} \text { in } 25 \%(\mathrm{v} / \mathrm{v}) \mathrm{HOAc}\end{array}$ & $6 \mathrm{~h}$ & $963{ }^{\circ} \mathrm{C}$ \\
\hline Organic matter/Sulfides & $\begin{array}{l}8 \mathrm{~mL} 30 \% \mathrm{H}_{2} \mathrm{O}_{2} \\
\left(\mathrm{pH}=2.0 \text { with } \mathrm{HNO}_{3}\right)\end{array}$ & $5 \mathrm{~h}$ & $853^{\circ} \mathrm{C}$ \\
\hline Residual & $\begin{array}{l}3 \mathrm{~mL} \mathrm{H}_{3} \mathrm{PO}_{4} \\
5 \mathrm{~mL} \mathrm{HCl} \\
1 \mathrm{~mL} \mathrm{HF}\end{array}$ & $1 \mathrm{~h}$ & Microwave-oven $\left(220^{\circ} \mathrm{C}\right)$ \\
\hline Water soluble & $\mathrm{L}: \mathrm{S}=10 \mathrm{ml}$ water: $1 \mathrm{~g}$ sample $^{\mathrm{a}}$ & $1 \mathrm{~h}$ & $25^{\circ} \mathrm{C}$ \\
\hline
\end{tabular}

${ }^{\text {a }}$ Sample weight: $100 \mathrm{~g}$. 

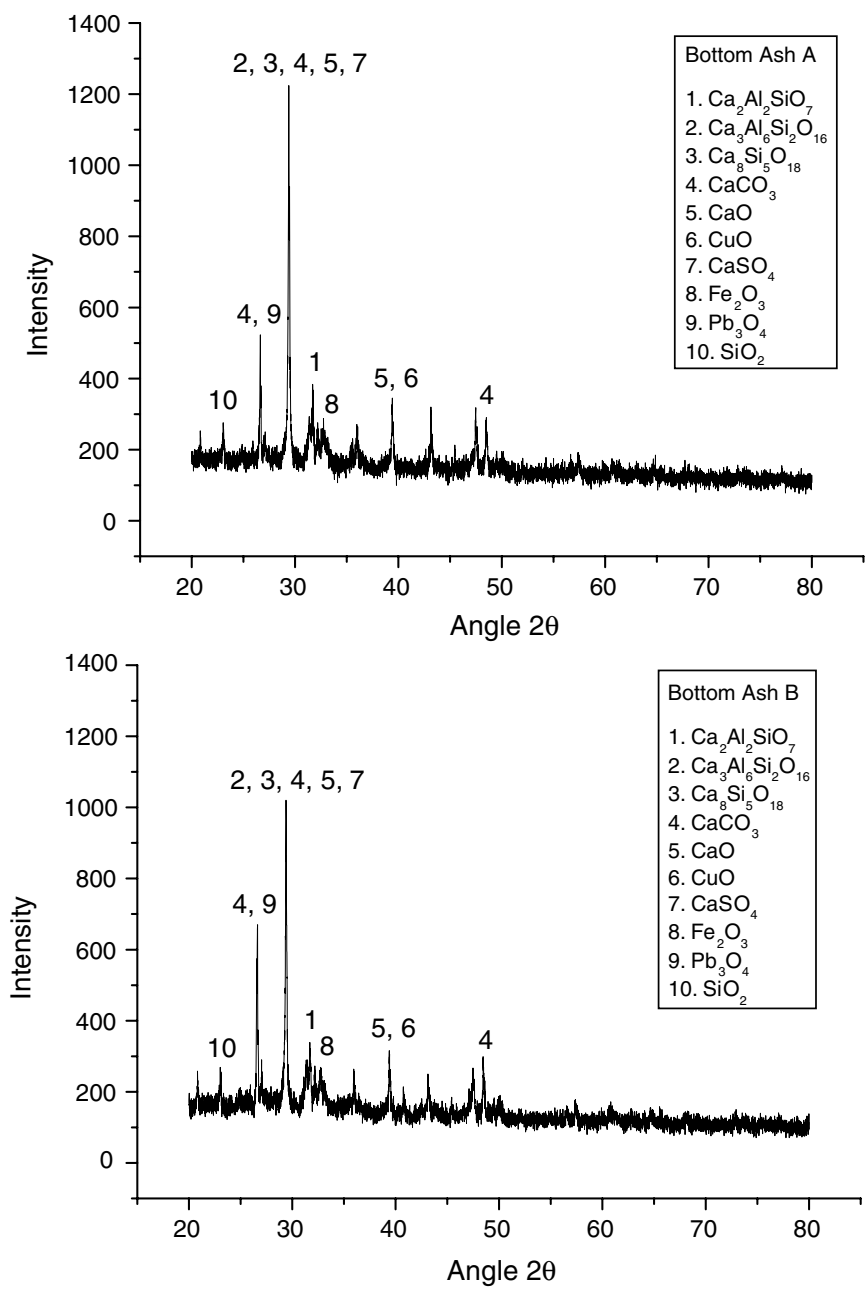

Fig. 1. XRD diagrams for two raw bottom ash samples.

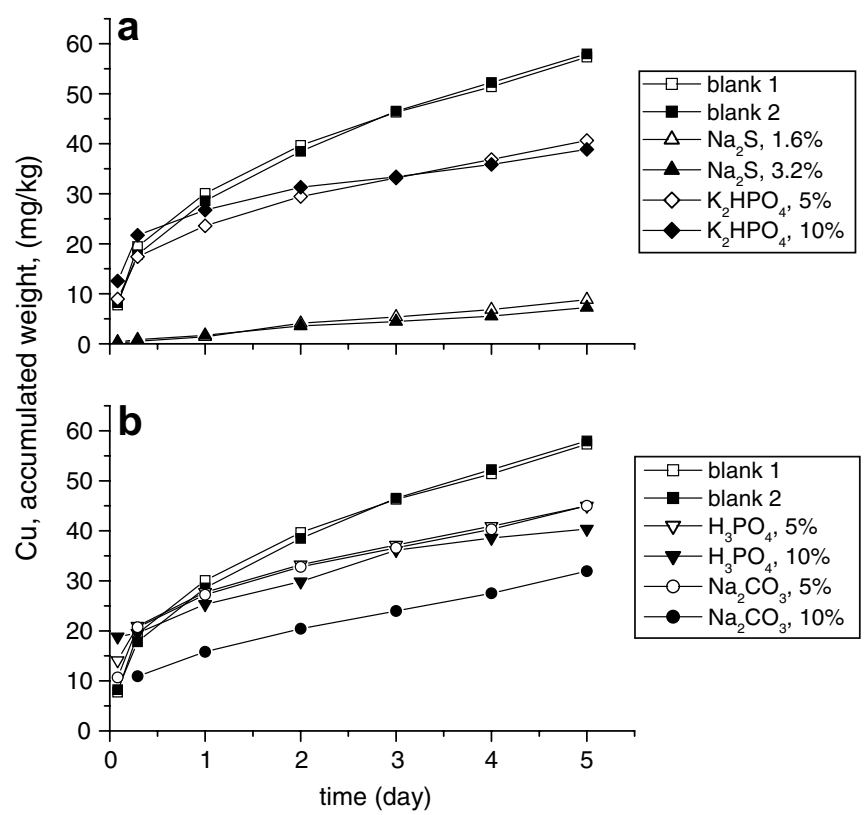

Fig. 2. Dynamic leaching tests with the addition of different stabilizing agents for bottom ash sample A. original $\mathrm{Cu}$ content). The initial high $\mathrm{pH}$ of ash samples is responsible for a small amount of $\mathrm{Cu}$ release. The two duplicate runs show essentially the same results. The concentrations used in all stabilizing agents were relatively high, resulting in an insignificant difference between two dosages used for each agent, except for $\mathrm{Na}_{2} \mathrm{CO}_{3}$ in which $10 \% \mathrm{Na}_{2} \mathrm{CO}_{3}$ showed a lower $\mathrm{Cu}$ leaching. For comparison, Meima et al. (2002) indicate $50 \% \mathrm{Cu}$ leaching reduction with artificial carbonation with $\mathrm{CO}_{2}$ to $\mathrm{pH} 8.3$ and Crannell et al. (2000) reported $95 \% \mathrm{Cu}$ leaching reduction with $3.6 \%$ soluble $\mathrm{PO}_{4}^{3-}$ addition. The $\mathrm{Na}_{2} \mathrm{~S}$, among four stabilizing agents evaluated, demonstrated the lowest $\mathrm{Cu}$ leaching (only about $5 \mathrm{mg} / \mathrm{kg}$ ), apparently due to the high stability of $\mathrm{Cu}-\mathrm{S}$ precipitates. For comparison, $10 \% \mathrm{Na}_{2} \mathrm{CO}_{3}$ yielded about $30 \mathrm{mg} \mathrm{Cu} / \mathrm{kg}$ and $5-10 \%$ phosphate $35 \mathrm{mg} / \mathrm{kg}$ with $55 \mathrm{mg} / \mathrm{kg}$ without addition of any stabilizing agent. The surface oxidation products vary with $\mathrm{pH}$ and oxidizing conditions. Zhou et al. (1999) indicated that $\mathrm{Cu}-\mathrm{S}$ bonding is stable during the oxidation treatment. In aqueous solution under alkaline conditions, $\mathrm{Cu}_{2} \mathrm{~S}$ might be oxidized to $\mathrm{CuO}$, and that is the most stable oxide phase under all $\mathrm{pH}$ conditions (Todd and Sherman, 2003). Based on the results of this study and previous research efforts, oxidation might proceed; however, the process should be kinetically fairly slow in anoxic environments where the bottom ash is reused. In other words, even with oxidation process, $\mathrm{Na}_{2} \mathrm{~S}$ is an effective stabilizing agent for bottom ash. Consequently, $\mathrm{Na}_{2} \mathrm{~S}$ was used in the subsequent column studies.

The column test results indicate much higher cumulative $\mathrm{Cu}$ leaching amounts compared to $\mathrm{Pb}$ and $\mathrm{Ni}$ (Fig. 3), since $\mathrm{Cu}$ content in the ash sample is much higher than that of other metals. Because of the nature of the HAc leaching solution, $\mathrm{pH}$ values decreased with time, or dropped from the initial 8.5 to 7.2 after $30 \mathrm{~d}$ (Fig. 3). The Cu leached quantity after 30 -d column test was only about $1.5 \%$ of the original $\mathrm{Cu}$ content present in the ash sample. The cumulated metal mass profiles (Fig. 3b) indicate relatively linear increases in metal leaching up to day 30 . Thus a long-term metal leaching evaluation should be conducted to determine the further extent of metal leaching. As for sample $\mathrm{B}$, the results are similar (data not shown) with about $1 \%$ the initial $\mathrm{Cu}$ content $(6600 \mathrm{mg} / \mathrm{kg})$ leaching out after the 30-d column test.

For long-term column studies, there is almost no appreciable $\mathrm{Cu}$ leaching for the sample with the addition of $1.6 \%$ $\mathrm{Na}_{2} \mathrm{~S}$ even after $180 \mathrm{~d}$ (Fig. 4). For comparison, the $\mathrm{Cu}$ release in the column containing sample $\mathrm{A}$ was about $270 \mathrm{mg}$ or $5.1 \%$ of the $\mathrm{Cu}$ content (Fig. 4); the increased cumulative amount is about 10 -fold from 1 mo to $6 \mathrm{mo}$ (Figs. 3 and 4). It is noted that the amount of $\mathrm{Cu}$ leaching for sample B is less (about $190 \mathrm{mg}$ after 6 mos; data not shown) despite the fact it contains a higher $\mathrm{Cu}$ content $(0.66 \%$ as compared to $0.53 \%$ in sample A). Consequently, the $\mathrm{Cu}$ content per se does not necessarily determine the extent of metal leaching; other factors are also involved, including the nature of metal speciation or metal binding within the solid matrix. 

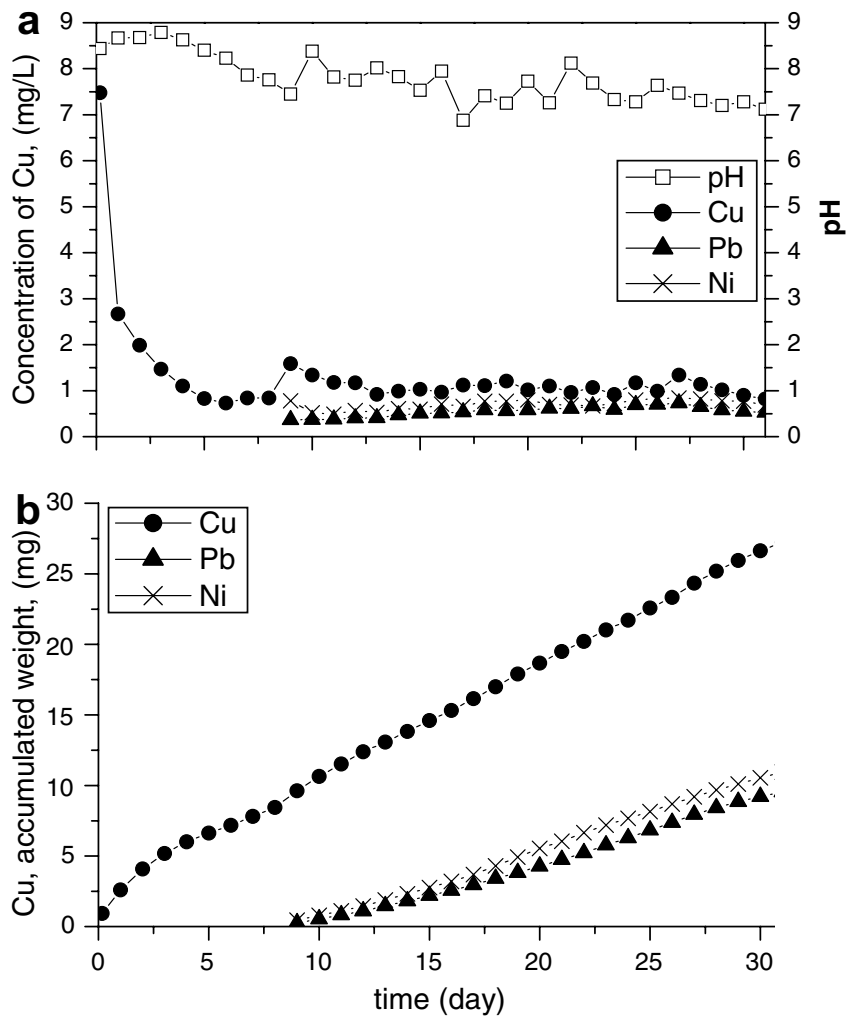

Fig. 3. Metal leaching from 30-d column tests (sample A).

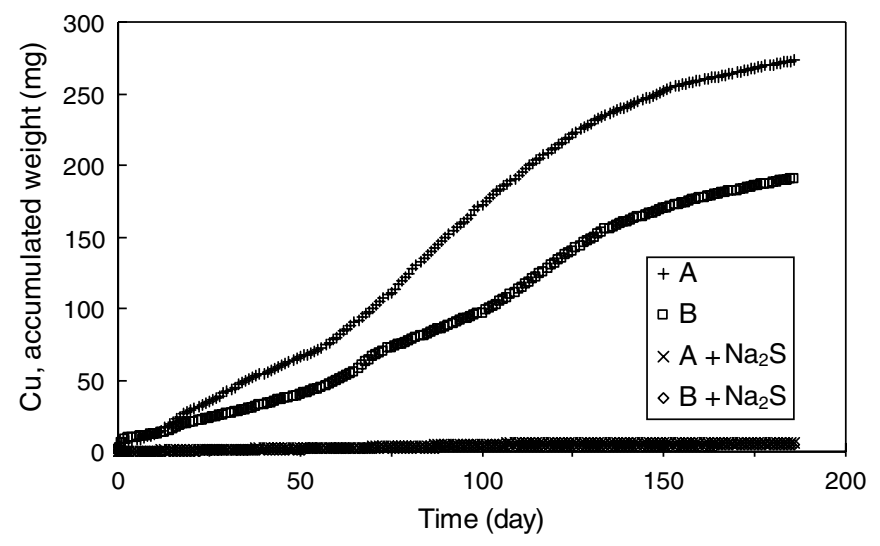

Fig. 4. Long-term 180-d cumulative $\mathrm{Cu}$ concentration from column test $\mathrm{Na}_{2} \mathrm{~S}$ at $1.6 \%$.

Hirschmann and Forstner (2000) have concluded that calcite buffering capacity would last a long time between $\mathrm{pH} 7$ and 8 . The minimum $\mathrm{Cu}$ release at $\mathrm{pHs}$ between 8 and 9 of the bottom ash upon addition of sorbing compounds was also reported (Comans et al., 2000). Consequently, unless $\mathrm{pH}$ drops to a lower level, the metal leaching in general and $\mathrm{Cu}$ in particular would not exhibit a significant amount.

\subsection{Sequential metal extraction}

The sequential extraction results of $\mathrm{Cu}$ partition are shown in Table 3. The total $\mathrm{Cu}$ content in different frac- tions varied from 85 to $102 \%$ of the $\mathrm{Cu}$ content determined from the mixed acid digestion method. For the raw bottom ash, the $\mathrm{Cu}$ bound to oxides constitutes a major fraction $(43 \%)$, with the next higher fraction being the residual (34\%) and approximately the same amount bound to carbonate and associated with organics/sulfide (ca. 10\% each). Since bottom ash is a product of the combustion process, the presence of high metal-oxides/hydroxides is expected, and $\mathrm{Cu}$ should be easily adsorbed onto $\mathrm{Fe} / \mathrm{Al} / \mathrm{Mn}$ (hydr)oxides and/or existence as $\mathrm{CuO}$ and $\mathrm{Cu}(\mathrm{OH})_{2}$ (Meima et al., 1999). Since extensive complexation with dissolved organics has been reported for $\mathrm{Cu}(>95 \%)$ in bottom ash leachate (Meima et al., 1999) and the fact of the ignition loss is still about $5 \%$, a $10 \%$ of $\mathrm{Cu}$ bound to organic is not unreasonable. For comparison, the $\mathrm{Cu}$ fractions for exchangeable, carbonate, oxides, organic and residue for soil are approximately $0.5 \%, 5 \%, 16 \%, 47 \%$ and $31 \%$, respectively (Tao et al., 2003); for sediments, more than $96 \%$ of $\mathrm{Cu}$ are bound to organic/sulfide fraction (Pardo et al., 1990); and for bottom ash $64 \%$ of $\mathrm{Cu}$ bound to organic and sulfide fraction (Bruder-Hubscher et al., 2002).

After the addition of $1.6 \% \mathrm{Na}_{2} \mathrm{~S}$ stabilizing agent, the $\mathrm{Cu}$ partition distribution is completely changed. Clearly, for whatever mechanisms, $\mathrm{Cu}$ previously associated with carbonate, $\mathrm{Fe} / \mathrm{Mn}$ and organics now is converted into some $\mathrm{Cu}-\mathrm{S}$ compounds resulting in a significant increase in the fraction bound to sulfide (21\%, Table 3). Further, the residual amount also increases significantly and these two fractions (sulfide and residual) amount to $85 \%$ of the total extractable $\mathrm{Cu}$; for comparison, it is only $44 \%$ with the raw sample without the addition of $\mathrm{Na}_{2} \mathrm{~S}$. High proportions of exchangeable and carbonate fractions enable metals to be easily removed from the bottom ash. In contrast, high percentages of $\mathrm{Fe}-\mathrm{Mn}$ oxides, organicmatter and residual fractions tended to fix the metals in the bottom ash, which was therefore stable, and metal might be released from those organic matter and subsequently binding with sulfide to form thermodynamically more stable species $(\mathrm{CuS})$. One can be sure that some fractions of organic matter remain in the bottom ash and both dissolved and particulate organic matters may play some roles in binding metals. The high fraction of residual, as well as the increased $\mathrm{Cu}-\mathrm{S}$ content, is certainly responsible for the insignificant $\mathrm{Cu}$ leaching even after the 180-d column with the HAc leaching solution as described before.

The ash residual present in the column after 1 mo of operation was removed and further subject to sequential extraction to observe the extent of changes in $\mathrm{Cu}$ partition. Many observations can be made of the Table 3 data. First, the $\mathrm{Cu}$ content associated with organics increased, from 420 to $610 \mathrm{mg} / \mathrm{kg}$ (50\% more), apparently due to the addition of HAc - either $\mathrm{Cu}$ directly reacts with HAc or with other organics due to the addition of HAc. If the inorganic acid were used as the leaching solution, it would be expected that $\mathrm{Cu}$ bound to organics should be significantly reduced. Secondly, the amount of $\mathrm{Cu}$ bound to carbonate 
Table 3

Results of sequential $\mathrm{Cu}$ extraction for sample $\mathrm{A}$ in $\mathrm{Cu}$ content $(\mathrm{mg} / \mathrm{kg})$ and percentage $(\%)$

\begin{tabular}{|c|c|c|c|c|c|c|}
\hline & \multicolumn{2}{|c|}{ Raw bottom ash } & \multicolumn{2}{|c|}{ Ash with $1.6 \% \mathrm{Na}_{2} \mathrm{~S}$} & \multicolumn{2}{|c|}{$\begin{array}{l}\text { Residual ash after } 1 \text { mo of } \\
\text { operation }\end{array}$} \\
\hline & Content & Percentage & Content & Percentage & Content & Percentage \\
\hline Exchangable & 45 & 1 & 30 & $<1$ & 5 & $<1$ \\
\hline Bound to carbonate & 460 & 11 & 100 & 2 & 300 & 9 \\
\hline Bound to $\mathrm{Fe}-\mathrm{Mn}$ oxides & 1790 & 43 & 545 & 12 & 870 & 27 \\
\hline Bound to organics/sulfide & 420 & 10 & 980 & 21 & 610 & 19 \\
\hline Residual & 1400 & 34 & 2975 & 64 & 1490 & 45 \\
\hline Total & 4115 & 100 & 4630 & 100 & 3275 & 100 \\
\hline Acid digested & 4040 & & 4731 & & 3855 & \\
\hline Recovery $(\%)$ & 102 & & 98 & & 85 & \\
\hline
\end{tabular}

and $\mathrm{Fe} / \mathrm{Mn}$ oxides was also reduced. Specifically, the $920 \mathrm{mg} / \mathrm{kg} \mathrm{Cu}$ reduction bound to $\mathrm{Fe} / \mathrm{Mn}$ (from 1790 to $870 \mathrm{mg} / \mathrm{kg})$ is almost $5-6$-fold $(160 \mathrm{mg} / \mathrm{kg})$ that of $\mathrm{Cu}$ bound to carbonate (from 460 to $300 \mathrm{mg} / \mathrm{kg}$ ). This implies that $\mathrm{Cu}$ bound to $\mathrm{Fe} / \mathrm{Mn}$ oxides is more easily leaching out than that bound to carbonate. Thirdly, the residual fraction increased to $45 \%$ as compared to $34 \%$ in the original sample. In short, the sequential extraction results do provide useful information in explaining the inability of $\mathrm{Cu}$ leaching in the $\mathrm{Na}_{2} \mathrm{~S}$ system, and elucidate the $\mathrm{Cu}$ affinity for different structures after 1 mo of leaching.

Additionally, a simple water rinse (mixing for $1 \mathrm{~h}$ of $1 \mathrm{~g}$ ash sample with $10 \mathrm{~mL}$ water) yielded $\mathrm{Cu}$ leachate amount of $1.1 \%$ of total $\mathrm{Cu}$ content, although the $\mathrm{L} / \mathrm{S}$ (liquid to solid ratio) of HAc leaching in dynamic tests $(20 \mathrm{ml} / \mathrm{g}$ ash) exceeded that in the water rinse tests $(10 \mathrm{ml} / \mathrm{g}$ ash). The amount of $\mathrm{Cu}$ leaching in fact is higher than that either from dynamic or column tests within the same time frame $(1 \mathrm{~h})$. More surprisingly, a significant fraction of $\mathrm{Cu}(0.32 \%)$ is also leached out with the $1.6 \% \mathrm{Na}_{2} \mathrm{~S}$ stabilized sample. The effectiveness of water wash for removing metals has also been reported for MSW residues of bottom and fly ash (Kim et al., 2003) and arsenic form copper smelting solid wastes (Shih and Lin, 2003). If a simple water wash is effective, it indicates that the water dissolved organic fraction may be present in a relatively large fraction. In fact, Dugenest et al. (1999) have reported that the labile organic carbon fraction in bottom ash is relatively high (about $1500 \mathrm{mg}$ / $\mathrm{kg}$ ), which includes mainly carboxylic acids, $n$-alkanes and phthalates. This proposition apparently contradicts the $\mathrm{Cu}$-fluvic complexes reported by others, since fulvic acid type components and not aliphatic and aromatic acids are responsible for $\mathrm{Cu}$ binding and eventually enhanced $\mathrm{Cu}$ leaching (van Zomeren and Comans, 2004). Nevertheless, the $\mathrm{Cu}$ release due to water alone and, to some extent, resultant biological activity may explain the different metal leaching between fresh and weathered bottom ashes (Meima and Comans, 1999; Meima et al., 1999; Chimenos et al., 2000). Additionally, this study suggests that $\mathrm{Cu}$ (or $\mathrm{Cu}$ oxide) in the leachate may be adsorbed again onto the ash.

\section{Conclusions}

Since only a few studies of the long-term metal leaching and metal fraction into different solid matrices in bottom ash had been conducted, the present study was undertaken to investigate these phenomena. The bottom ash samples were taken from two different MSW incinerators, subjected to XRD and elemental analysis and eventually used for metal leaching tests with acetic acid ( $\mathrm{pH}$ 5.2) as the leaching solution.

As would be expected, the samples contain minerals typically with different calcium-hydrate phases, including $\mathrm{Ca}_{3} \mathrm{Al}_{6} \mathrm{Si}_{2} \mathrm{O}_{16}, \mathrm{Ca}_{8} \mathrm{Si}_{5} \mathrm{O}_{18}, \mathrm{CaCO}_{3}, \mathrm{CaSO}_{4}, \mathrm{CaO}, \mathrm{CuO}$, $\mathrm{Pb}_{3} \mathrm{O}_{4}$ and $\mathrm{SiO}_{2}$. The high $\mathrm{pH}$ along with these oxides is responsible for a relatively small amount of leaching, e.g., only $1 \%$ for the 5 -d ANS batch test and $1.5 \%$ after $30-\mathrm{d}$ column operation. This implies that only a fairly small fraction of $\mathrm{Cu}$ could be released from the reused ash matrix into the environment in about 4.4 years. The addition of three different types of stabilizing agent $\left(\mathrm{PO}_{4}^{3-}, \mathrm{CO}_{3}^{2-}\right.$ and $\left.\mathrm{S}^{2-}\right)$ in bottom ash reduced the amount of $\mathrm{Cu}$ leaching, with $1.6 \%$ $\mathrm{Na}_{2} \mathrm{~S}$ yielding an insignificant amount. The formation of $\mathrm{Cu}_{2} \mathrm{~S}$ eventually might be oxidized to $\mathrm{CuO}$ phase. However, the transformation of $\mathrm{Cu}_{2} \mathrm{~S}$ into $\mathrm{CuO}$ under an anoxic condition is kinetically insignificant, thus securing the environmental risk of bottom ash reuses. In other words, whether the oxidation progressed or not, $\mathrm{Na}_{2} \mathrm{~S}$ is an effective stabilizing agent for bottom ash.

There is a definite trend of the linear $\mathrm{Cu}$ leaching for the $30-\mathrm{d}$ column test. Therefore, a long-term of $180-\mathrm{d}$ column test was conducted to see the further extent of $\mathrm{Cu}$ leaching. At the end of $180 \mathrm{~d}$, the $\mathrm{Cu}$ leaching amount is about $5.1 \%$ for Sample A and the cumulative profile indicated the potential further leaching. The impact of this observation is of significance since it may present a long-term problem if there is no pretreatment to fix metals. Nevertheless, with the addition of $\mathrm{Na}_{2} \mathrm{~S}$, the $\mathrm{Cu}$ leaching can be completely inhibited.

The sequential extraction of raw ash, ash with the addition of $1.6 \% \mathrm{Na}_{2} \mathrm{~S}$ and residual ash after the 30-d operation shows different $\mathrm{Cu}$ amount towards five fractions (exchangeable, carbonate, $\mathrm{Fe} / \mathrm{Mn}$, organics/sulfide 
and residue). The fraction associated with sulfide increased significantly for the ash sample with addition of $\mathrm{Na}_{2} \mathrm{~S}$, confirming the $\mathrm{Cu}$ fixation and thereafter the inhibition of $\mathrm{Cu}$ leaching was primary due to the association between $\mathrm{Cu}$ species and $\mathrm{Na}_{2} \mathrm{~S}$.

\section{Acknowledgement}

The authors thank the National Science Council of the Republic of China for financially supporting this research under Contract No. NSC 91-2211-E-002-009.

\section{References}

ANS, 1986. Measurement of the leachability of solidified low-level radioactive wastes by a short-term test procedure. American Nuclear Society. ANSI/ANS-16, American National Standards Institute, New York.

Baba, A., Kaya, A., 2004. The Leaching characteristics of solid wastes from thermal power plants of western Turkey and comparison of toxicity methodologies. Journal Environmental Management 73, 199207.

Bruder-Hubscher, V., Lagarde, F., Leroy, M.J.F., Coughanowr, C., Enguehard, F., 2002. Application of a sequential extraction procedure to study the release of elements from municipal solid waste incineration bottom ash. Analytica Chimica Acta 451, 285-295.

Chao, Y.N. 2003. Using dynamic/semi-dynamic leaching procedures to assess the long-term stabilization in bottom ash from municipal solid waste incinerator. Master Thesis, National Taiwan University, Taiwan (in Chinese).

Chimenos, J.M., Fernandez, A.I., Nadal, R., Espiell, F., 2000. Short-term natural weathering of MSWI bottom ash. Journal of Hazardous Materials 79, 287-299.

Comans, R.N.J., Meima, J.A., Geelhoed, P.A., 2000. Reduction of contaminant leaching from MSWI bottom ash by addition of sorbing components. Waste Management 20, 125-133.

Crannell, B.S., Eighmy, T.T., Krzanowski, J.E., Eusden, J.D., Shaw, E.L., Francis, C.A., 2000. Heavy metal stabilization in municipal solid waste combustion bottom ash using soluble phosphate. Waste Management 20, 135-148.

Dugenest, S., Casabianca, H., Greniner-Loustalot, M.F., 1999. Municipal solid waste incineration bottom ash: physicochemical characterization of organic matter. Analysis 27, 75-81.

Hirschmann, G., Forstner, U., 2000. Long-term assessment for the leachate release of heavy metals from municipal solid waste incineration. Acta Hydrochimica et Hydrobiologica 28, 262-271.

Iretskaya, S., Nzihou, A., Zahraoui, C., Sharrock, P., 1999. Metal leaching from MSW fly ash before and after chemical and thermal treatments. Environmental Progress 18, 144-148.

Johnson, C.A., Kersten, M., Ziegler, F., Moor, H.C., 1996. Leaching behaviour and solubility - controlling solid phases of heavy metals in municipal solid waste incinerator ash. Waste Management 16, 129 134.

Kim, S.Y., Matsuto, T., Tanaka, N., 2003. Evaluation of pre-treatment for landfill disposal of residues from municipal solid waste incineration. Waste Management Research 21, 416-423.
Meima, J.A., Comans, R.N.J., 1999. The leaching of trace elements from municipal solid waste incinerator bottom ash at different stages of weathering. Applied Geochemistry 14, 159-171.

Meima, J.A., van Zomeren, A., Comans, R.N.J., 1999. Complexation of $\mathrm{Cu}$ with dissolved organic carbon in municipal solid waste incinerator bottom ash leachates. Environmental Science and Technology 33, 1424-1429.

Meima, J.A., van der Weijden, R.D., Elghmy, T.T., Comans, R.N.J., 2002. Carbonation processes in municipal solid waste incinerator bottom ash and their effect on the leaching of copper and molybdenum. Applied Geochemistry 17, 1503-1513.

National Institute of Experimental Laboratory, 2004. Method for Soil Water Content (NIEA S280.61C), Method for Heavy Metal Analysis (NIEA M103.01C), Method for Ignition loss of ash (NIEA R216.01C), Taiwan.

Pardo, R., Barrado, E., Perez, L., Vega, M., 1990. Determination and speciation of heavy metals in sediments of the Pisuegra river. Water Research 24, 373-379.

Polettini, A., Pomi, R., 2004. The leaching behavior of incinerator bottom ash as affected by accelerated ageing. Journal of Hazardous Materials 113, 211-217.

Pshlsson, A.M.B., 1989. Toxicity of heavy metals $(\mathrm{Zn}, \mathrm{Cu}, \mathrm{Cd}, \mathrm{Pb})$ to vascular plant. Water Air Soil Pollution 47, 2749-2755.

Reich, J., Pasel, C., Herbell, J.D., Luckas, M., 2002. Effects of limestone addition and sintering on heavy metal leaching from hazardous waste incineration slag. Waste Management 22, 315-326.

Shih, C.J., Lin, C.F., 2003. Arsenic contaminated site at an abandoned copper smelter plant: waste characterization and solidification/stabilization treatment. Chemosphere 53, 691-703.

Speiser, C., Baumann, T., Niessner, R., 2000. Morphological and chemical characterization of calcium hydrate phases formed in alteration processes of deposited municipal solid waste incinerator bottom ash. Environmental Science and Technology 34, 5030-5037.

Stumm, W., Morgan, J.J., 1981. Aquatic Chemistry. John Wiley, New York.

Tao, S., Chen, Y.J., Xu, F.L., Cao, J., Li, B.G., 2003. Changes of copper speciation in maize rhizosphere soil. Environmental Pollution 122, $447-454$.

TEPA, 2004. The current status of municipal solid waste incinerators. Environmental Protection Administration, Taiwan. Available from: http://210.69.101.88/WEBSTATIS/webindex.htm.

Tessier, A., Campbell, P.G.C., Bisson, M., 1979. Sequential extraction procedure for the speciation of particulate trace metals. Analytical Chemistry 51, 844-851.

Todd, E.C., Sherman, D.M., 2003. Surface oxidation chalcocite $\left(\mathrm{Cu}_{2} \mathrm{~S}\right)$ under aqueous $(\mathrm{pH}$ 2-11) and ambient atmosphere conditions: Mineralogy from $\mathrm{Cu}$ L- and $\mathrm{O}$ K-edge X-ray absorption spectroscopy. American Mineralogist 88, 1652-1656.

van Gerven, T., van Keer, E., Arickx, S., Jaspers, M., Wauters, G., Vandecasteele, C., 2005. Carbonation of MSWI-bottom ash to decrease heavy metal leaching, in view of recycling. Waste Management 25, 291-300.

van Zomeren, A., Comans, R.N.J., 2004. Contribution of natural organic matter to copper leaching from municipal solid waste incinerator bottom ash. Environmental Science and Technology 38, 3927-3932.

Zhou, W., Hesterberg, D., Hansenm, P.D., Hutchison, K.J., Sayers, D.E., 1999. Stability of copper sulfide in a contaminated soil. Journal of Synchrotron Radiation 6, 630-632. 